\title{
A review of Nagssugtoqidian palaeomagnetism
}

\author{
George E. J. Beckmann
}

\begin{abstract}
Introduction
Palaeomagnetic research in the Nagssugtoqidian mobile belt of West Greenland has been carried out by Beckmann \& Mitchell (1976) and by Morgan (1976a, b) near the boundary with the Archaean, and by Beckmann et al. (1977) in Nordre Strømfjord and on the mountain Kællingehætten at Holsteinsborg. Fahrig \& Bridgwater (1976) investigated both the Archaean and the Nagssugtoqidian. In East Greenland the author has determined palaeomagnetic poles for rocks in the Angmagssalik district. North-West Scotland is believed to have been attached to Greenland and so it is relevant to include remarks about the palaeomagnetism of the Lewisian.

The palaeomagnetic work was undertaken mainly to elucidate the thermal history of these rocks. In the course of the investigations there were important changes in the basic ideas concerning the mechanism of magnetization in metamorphic terrains, and the work in Greenland has helped to bring these about.

Traditionally, palaeomagnetism has relied primarily on igneous rocks intruded into cold crust because these would ideally have been magnetized at specific points in time and be undeformed, so that the directions of magnetization would be the same as the ancient field directions at the times of emplacement. Work on metamorphic terrains was avoided on account of the complex history of the rocks, the uncertainty of their magnetic age and their deformed character. Nevertheless palaeomagnetic work on gneisses has now been placed on a routine basis, especially since the publication of a method for correcting for deflexion of the magnetization in deformed rocks (Beckmann et al., 1977). Even shear zones in West and East Greenland have been successfully treated by this method. Sampling is nowadays carried out in regions of geological interest irrespective of the absence of undeformed igneous rocks. Moreover the inclusion of metamorphic rocks in palaeomagnetic investigations removes the objection that palaeomagnetic results are selective in both time and tectonic situation (Badham, 1976).

The traditional work on igneous bodies caused thinking about the temperature of magnetization to be dominated by the Curie point $\left(578^{\circ} \mathrm{C}\right.$ in magnetite). However in metamorphic terrains, cooling was so slow that the magnetization was able to follow the Earth's field direction until the rocks were much cooler than the Curie point, perhaps as low as $200^{\circ} \mathrm{C}$ (Ueno et al., 1975; Irving et al., 1974). This point of view was expressed in detail by Morgan (1976a) who suggested that magnetization occurred within a limited range of depths in the crust during slow cooling due to uplift and unroofing. If reversals of the Earth's magnetic
\end{abstract}


field took place several times per million years, like the last few million years, cooling between reversals might only be of the order of $1^{\circ} \mathrm{C}$, so that the rocks would not acquire any magnetization. Therefore magnetization during slow cooling requires the polarity of the Earth's field to be constant, or at least predominantly of one sense (Beckmann, 1976). A palaeomagnetic advantage of this mechanism is that secular variation is averaged out, so that the poles are true palaeomagnetic poles and not virtual geomagnetic poles, and can often be obtained with high precision. As Morgan recognized, a consequence of the slow cooling model is that in terrains containing early Proterozoic dykes, gneisses and dykes should display the same directions of magnetization. The first evidence to suggest that this was the case had come from the Lewisian (Beckmann, 1976).

The $\mathrm{K}$-Ar method of dating is of value in estimating the age of magnetization because the argon blocking temperature for biotite, typically $200-300^{\circ} \mathrm{C}$ (Dalrymple \& Lanphere, 1969 , p. 157), is similar to that of the magnetization during slow cooling. The determination of isochron plots, based on ages from whole rocks and mineral fractions, enables excess argon to be accounted for, with a consequent reduction in the spread of data typically seen in whole-rock analyses from high-grade terrains. This point is well illustrated by the work of Mitchell in West Greenland (Beckmann \& Mitchell, 1976).

Nevertheless, caution is needed before correlating magnetic and K-Ar ages in slowly cooled terrains, even when such ages have been derived by the isochron method. This is because even a small difference in blocking temperature may correspond to a large time difference during slow cooling. It is also important to establish whether the magnetization resides in magnetite or haematite.

The palaeomagnetic work in the Nagssugtoqidian mobile belt (overlapping with the Archaean) will be reviewed in the light of this introducion to some current thinking in Precambrian palaeomagnetism.

\section{West Greenland}

\section{Nagssugtoqidian/Archaean boundary}

Fahrig \& Bridgwater (1976) determined directions of magnetization for 23 Kangâmiut dykes, of which 3 were just north of the boundary near Itivdleq. They found a common direction of magnetization for the dykes showing that they have a common magnetic age, uninfluenced by the presence of the boundary at which they change their strike direction from NNE in the Archaean to ENE along Itivdleq. The palaeomagnetic pole for the dykes is at $17.1^{\circ} \mathrm{N}, 273.8^{\circ} \mathrm{E}$.

In the Godthåb district these authors found that the pole for the gneisses is at $20^{\circ} \mathrm{N}$, $274^{\circ} \mathrm{E}$. They thus beautifully vindicated the prediction that early Proterozoic dykes will have the same direction of magnetization as the gneisses in slowly cooled terrains, although they regarded the concordance as "a bit surprising". They noted that in the Godthåb district there had been regional metamorphism at 1600-1700 Ma which reset the Rb-Sr mineral ages and partially reset K-Ar ages in hornblende and biotite (Pankhurst et al., 1973). However Fahrig \& Bridgwater sought to minimize the effect of this thermal event on the magnetization. They considered the magnetic age of the gneisses to be $2500 \mathrm{Ma}$; moreover the K-Ar evidence suggested that the dykes were emplaced at $2500 \mathrm{Ma}$. The view was advanced that the dykes were magnetized at or near the time of emplacement. This can 
hardly be true on account of the following reasoning. At Itivdleq there is strong geological evidence that the gneisses were at metamorphic temperatures when the dykes were intruded (Watterson, 1974). Therefore the dykes there were magnetized long after emplacement. Fahrig \& Bridgwater had established that the magnetic age of dykes at Itivdleq and in the Archaean craton was the same. Therefore the magnetization in the latter was also imposed long after emplacement. These authors noted that their palaeomagnetic poles fell on a certain polar wander path at 1800-2000 Ma but preferred to rely upon the K-Ar whole rock ages of the dykes to estimate their magnetic age at about $2500 \mathrm{Ma}$. Recent evidence indicating that the dykes were emplaced at $1950 \mathrm{Ma}$ renders this impossible and so the younger magnetic age, at least for the dykes, is now accepted (Kalsbeek et al., 1978).

Fahrig \& Bridgwater compared the direction of magnetization of the dykes with two gneiss samples near Kangâmiut and showed that they were different. Their conclusion that, in general, the direction of magnetization in the gneisses and dykes in the craton are different, was unsound. A statistical test of this point would be important to establish whether the direction of magnetization observed in the gneisses near Godthåb is a local phenomenon, due to the metamorphic event there, or whether the same direction of magnetization exists generally in the Archaean craton.

The work of Morgan (1976b) included palaeomagnetic investigation of two gneiss sites in the Archaean craton, immediately to the south of the boundary with the Nagssugtoqidian; he found that directions of magnetization show no obvious change upon crossing the boundary. In contrast there is an abrupt change in $\mathrm{K}-\mathrm{Ar}$ isochron ages of the gneisses, from $1700 \pm$ 40 and $1830 \pm 20 \mathrm{Ma}$ near Itivdleq to $2410 \pm 40 \mathrm{Ma}$ just $1 \mathrm{~km}$ south of the boundary (Beckmann \& Mitchell, 1976). The latter site was the same as one of Morgan's two sites. The implication is that the magnetization was established much later than the closure of the isotopic system, at least in the Archaean craton.

Beckmann \& Mitchell (1976) obtained a palaeomagnetic pole for dykes at Itivdleq near that of Fahrig \& Bridgwater (1976) and suggested that their magnetic age was $1750 \mathrm{Ma}$ on the basis of their whole rock ages, which are close to the $\mathrm{K}-\mathrm{Ar}$ isochron ages of the local gneisses. These were all interpreted as regional cooling ages following the Nagssugtoqidian metamorphism, and accord with the earlier K-Ar mineral ages of 1790-1650 Ma for the Nagssugtoqidian mobile belt (Larsen \& Møller, 1968). In the Itivdleq area too, Morgan (1976a) obtained palaeomagnetic poles for the dykes and gneisses which were similar to each other, in accordance with the regional cooling hypothesis.

Palaeomagnetic work was also carried out by Fahrig \& Bridgwater on three Kangâmiut dykes on Sagdlerssuaq which had been deformed by the second Nagssugtoqidian phase, Nag. 2 (Bridgwater $e$ t al., 1973). For these they calculated a more northerly palaeomagnetic pole (Table 1) and considered this to be younger than that determined for the dykes to the south. Beckmann \& Mitchell (1976) found that the K-Ar isochron age of basic gneiss bands on Sagdlerssuaq is $1620( \pm 50) \mathrm{Ma}$, which confirmed this interpretation. The latter authors also obtained a palaeomagnetic pole for these bands, and this is not significantly different from Fahrig \& Bridgwater's pole (at the $95 \%$ confidence level). Ketilidian metavolcanics magnetized at 1650 Ma have also yielded similar poles (Piper \& Stearn, 1976). These poles could not initially be reconciled with the few results of similar age from North America. However the North American polar wandering path has just been completely altered at $1650 \mathrm{Ma}$ in view of these poles from Greenland and three similar poles from North America (Irving, 1979). The direction of magnetization on Sagdlerssuaq has recently been corrected 
for anisotropy of susceptibility by the method of Beckmann et al. (1977) and has given an inclination of $86.0^{\circ}$, indistinguishable from that of $88.6^{\circ}$ from the undeformed Kangâmiut dyke on the neighbouring island of Sarqaq.

\section{Kallingehatten and Nordre Strømfjord}

The theory of magnetization during slow cooling was tested by sampling up the mountain Kællingehætten near Holsteinsborg (Beckmann et al., 1977). According to the theory, the site near the top should display older magnetization than those at lower levels. Altogether five sites were occupied. About twenty-five samples were drilled per site, so as to define the mean direction of magnetization at each site as accurately as practicable. A complex polar wander resulted which could have represented the fine structure of apparent polar movement during the cooling history of the mountain. However there was no independent evidence to support this interpretation.

The slow cooling theory of magnetization was assumed by the same authors in an experimental test of the geological model of the Nordre Strømfjord shear zone (Bak et al., 1975) in which the eastern end of the fjord is believed to represent an original crustal level about 10 $\mathrm{km}$ higher than that now exposed at the mouth. It had been hoped that this difference in crustal level would be manifested by a trend of palaeomagnetic poles of sufficient length to be related to the apparent polar wander path for North America. Nine sites along the fjord were selected and again about twenty-five orientated samples obtained at each site. Once more a complex polar wander path resulted which precluded a simple interpretation. De-

Table 1. Early Proterozoic palaeomagnetic poles for Greenland

\begin{tabular}{|c|c|c|c|c|c|}
\hline \multirow[t]{2}{*}{ Rock Suite } & \multicolumn{2}{|c|}{$\begin{array}{c}\text { Palaeomagnetic } \\
\text { Pole }\end{array}$} & \multirow{2}{*}{$\begin{array}{l}\text { Possible } \\
\text { Magnetic } \\
\text { Age, } \mathrm{Ma}\end{array}$} & \multirow[t]{2}{*}{ Authors } & \multirow[t]{2}{*}{ Notes } \\
\hline & $\mathrm{O}_{\mathrm{N}}$ & $0_{\mathrm{N}}$ & & & \\
\hline Godth@̊ gneisses & 20.0 & 274.0 & $1600-1700\}$ & Fahrig \& & \\
\hline Kangâmiut dykes & 17.1 & 273.8 & $<1950\}$ & Bridgwater (1976) & \\
\hline $\begin{array}{l}\text { Kangamiut dykes } \\
\text { (Itivdleq only) } \\
\text { Itivdleq region: } 18\end{array}$ & 18.0 & 287.2 & 1750 & Beckmann \& Mitchell (1976) & \\
\hline $\begin{array}{l}\text { Kangâmiut dykes and } 4 \\
\text { gneisses }\end{array}$ & 14.0 & 285.0 & $1650-1790^{\circ}$ & Morgan (1976 a) & 1 \\
\hline Angmagssalik gneisses & 24.0 & 272.0 & $1600-1800$ & Herein & 2 \\
\hline $\begin{array}{l}\text { Nordre Stromfjord } \\
\text { gneisses } \\
\text { K allingeh tten gneisses }\end{array}$ & $\begin{array}{l}27 \cdot 7 \\
25 \cdot 3\end{array}$ & $\begin{array}{l}276.6 \\
300.4\end{array}$ & $\left.\begin{array}{r}1710^{*} \\
1650-1790^{*}\end{array}\right\}$ & Beckmann et al. (1977) & \\
\hline Nordfjord gneisses & -9.6 & 250.2 & $\begin{array}{l}>1750 \\
<1950\end{array}$ & Herein & 2 \\
\hline $\begin{array}{cl}\text { Sagdlerssuaq gneisses } \\
" 1 & \text { dykes } \\
" & \text { gneisses }\end{array}$ & $\begin{array}{l}56.9 \\
48.8 \\
70.0\end{array}$ & $\begin{array}{l}273 \cdot 6 \\
238 \cdot 2 \\
286.8\end{array}$ & $\begin{array}{r}1620(+50) \\
7620 \\
1620\end{array}$ & $\begin{array}{l}\text { Beckmann \& Mitchell }(1976) \\
\text { Fahrig \& Bridgwater }(1976)\end{array}$ & 3 \\
\hline Ketilidian West Arsuk Is & 58.8 & 278.5 & 1650 & Piper \& Stearn (1976) & \\
\hline $\left.\begin{array}{l}\text { Meta- } \\
\text { volcanics }\end{array}\right\}$ East Arsuk Is & 60.4 & 229.8 & 1650 & & \\
\hline
\end{tabular}

1. Morgan's published pole was at $13^{\circ} \mathrm{N}, 269^{\circ} \mathrm{E}$ but this had been corrected for drift of Greenland away from North America (Bullard et al., 1965).

2. Provisional data.

3. This is the data of Beckmann \& Mitchell (1976) corrected for anisotropy of susceptibility by the method of Beckmann et al., (1977).

*Larsen \& Møller (1968)。 
tailed polar movement could have occurred in this way. Therefore the result was consistent with the geological model but did nothing to support it.

In spite of these apparent failures, some valuable lessons were learnt. Perhaps most important, the strong fabric in the rocks of the shear zone rendered imperative the correction of the apparent directions of the ancient magnetic field for the deflexions arising from anisotropy of susceptibility. The authors devised a method of doing this which they verified experimentally and statistically. These extensive studies of gneisses demonstrated that palaeomagnetic investigation of metamorphic rocks is worthwhile and that partial thermal demagnetization can be an effective method of magnetic cleaning for gneisses, leading to sharp end-points. The curves obtained for both projects supported the view that, in detail, Precambrian polar wander occurred in closed loops (Piper \& Stearn, 1976).

A distinction can be drawn between this detailed movement and general trends. A mean palaeomagnetic pole was calculated for each of the two regions under discussion. It was then found that the mean poles for these two regions and for the Godthåb gneisses and for the Kangâmiut dykes lie remarkably close together. This proximity implies similar times for magnetization.

\section{East Greenland}

In 1976 the author was a member of GGU's expedition to East Greenland and collected 548 orientated samples of metamorphic rocks between Angmagssalik and Nordfjord, 125 $\mathrm{km}$ to the north-east (Beckmann, 1977). Provisional results will be summarized here. Three sites in Angmagssalik harbour yielded palaeomagnetic poles close to those of the Kangâmiut dykes. This accords with the similarity of radiometric ages. As has been noted, the Kangâmiut dykes have a K-Ar age of about $1750 \mathrm{Ma}$, whilst an age of 1600-1800 Ma has been suggested for the Angmagssalik complex (Bridgwater et al., 1977).

On the other hand in the Nordfjord district, characterized by Archaean gneisses in granulite facies, a different palaeomagnetic pole has been isolated from seven gneiss sites. Three of these are reversed with respect to the other four. A small shear zone on Storø, and a pseudotachylite in Nordfjord of hitherto unknown age, have the same magnetic ages as the local gneisses. The gneisses have been subjected to limited Nag. 2 deformation. The magnetization would have become fixed in the rocks during the subsequent cooling. The Angmagssalik complex was emplaced later than this deformation (Bridgwater et al., 1977, table 2) and therefore probably cooled later, although this has not been proved. Thus the age of magnetization in the Nordfjord area is likely to be greater than $1750 \mathrm{Ma}$. However it is probably not much older because Nag. 2 has recently been dated at 1950-1800 Ma in West Greenland (Kalsbeek et al., 1978). If this age is correct it also provides a minimum age for the formation of the pseudotachylite.

The presence of reversals in the Nordfjord gneisses also suggests that they were magnetized at a different time from the Kangâmiut dykes. The sense of the suggested time difference and the approximate dates accord with the apparent polar wander path for North America (Irving \& McGlynn, 1976). The reversals appear at first sight to violate the principle of magnetization during slow cooling, but this can be maintained by supposing that vertical faulting has resulted in the exposure of distinctly different crustal levels at the various sites, at each of which the polarity had predominantly one sense during cooling. The reversal frequency may have been lower for the early Proterozoic than at present (Bingham 
\& Evans, 1976). It would be interesting to test these proposals by sampling up a mountain in the Nordfjord area. The occurrence of reversals in gneisses is a potentially valuable stratigraphic tool.

A boundary striking east-west between major and minor deformation of the garnet-amphibolite dykes has been recognized by Bridgwater et al. (1977). To the south of this boundary almost no magnetically stable sites have been found until Angmagssalik. This recalls the situation in the Lewisian (Beckmann, 1976) in which magnetic stability is controlled by the presence of a metamorphic boundary.

\section{Comparison with North-West Scotland}

It is generally accepted that the Lewisian of North-West Scotland is a fragment of Greenland. A magnetic age af about $1800 \mathrm{Ma}$ was suggested for the Scourie dykes (Beckmann, 1976), indistinguishable from that proposed for the Kangâmiut dykes.

Assume that the reconstruction of Bullard et al. (1965) is correct for the position of Greenland next to Europe before the opening of the Norwegian Sea (fig. 1). This requires that Greenland is rotated from its present position by $-22.0^{\circ}$ about a pole at $73.0^{\circ} \mathrm{N}, 96.5^{\circ} \mathrm{E}$. Then Fahrig \& Bridgwater's palaeomagnetic pole for the Kangâmiut dykes would move to $16.1^{\circ} \mathrm{N}, 296.7^{\circ} \mathrm{E}$. Suppose that this is the correct pole for the Scourie dykes and then move their apparent poles into coincidence with it. In this way we can calculate palaeo-positions of the Lewisian with respect to Greenland. Consider the four most stably magnetized of the Scourie dykes (Table 2), as judged by the high values of precision parameter, $k \geq 166$, and by the steadiness of the direction of magnetization between demagnetizing steps; in these four dykes it seems certain that all spurious components of magnetization have been removed. Clearly the inclinations of the magnetization, $I$, are similar, indicating similar values of the palaeolatitude, $\lambda$, on account of the relation $\tan \lambda=1 / 2 \tan I$. The average value of the palaeolatitude is $30.2^{\circ}$ which is exactly that calculated from the present position of the Lewisian, in relation to the shifted Kangâmiut pole. (On the other hand the palaeolongitude is of course indeterminate). The declination of the magnetization from the Lewisian towards the shifted Kangâmiut pole would be expected to be $250.7^{\circ}$, whereas the mean declination observed at the four dykes is $280.4^{\circ}$. This suggests that the Lewisian has rotated clockwise by $30^{\circ}$ since the dykes were magnetized (fig. 1). The sense of rotation is confirmed by further palaeomagnetic work on the Scourie dykes by Williams (1975).

This conclusion agrees with observations of dyke strikes by Escher et al. (1976). In Scotland the Scourie dykes strike at $124( \pm 11)^{\circ}$, whereas in East Greenland an extension of the same swarm has a strike of $79( \pm 11)^{\circ}$. There is thus an apparent difference of strike of about $45^{\circ}$. Upon rotation of Greenland in accordance with the Bullard reconstruction, the

Table 2. Magnetization of Scourie dykes (Beckmann, 1976)

\begin{tabular}{llllc}
\hline Dyke No. & $\begin{array}{c}\text { Mean direction of magnetization } \\
\text { dec. }\end{array}$ & ags. & $\begin{array}{c}\text { Palaeo- } \\
\text { latitude } \lambda\end{array}$ \\
\hline 18 & 262.0 & 50.7 & 2.1 & 31.4 \\
24 & 294.0 & 49.6 & 3.2 & 30.4 \\
26 & 293.1 & 50.3 & 2.1 & 31.1 \\
28 & 272.4 & 46.6 & 1.9 & 27.9 \\
\hline
\end{tabular}




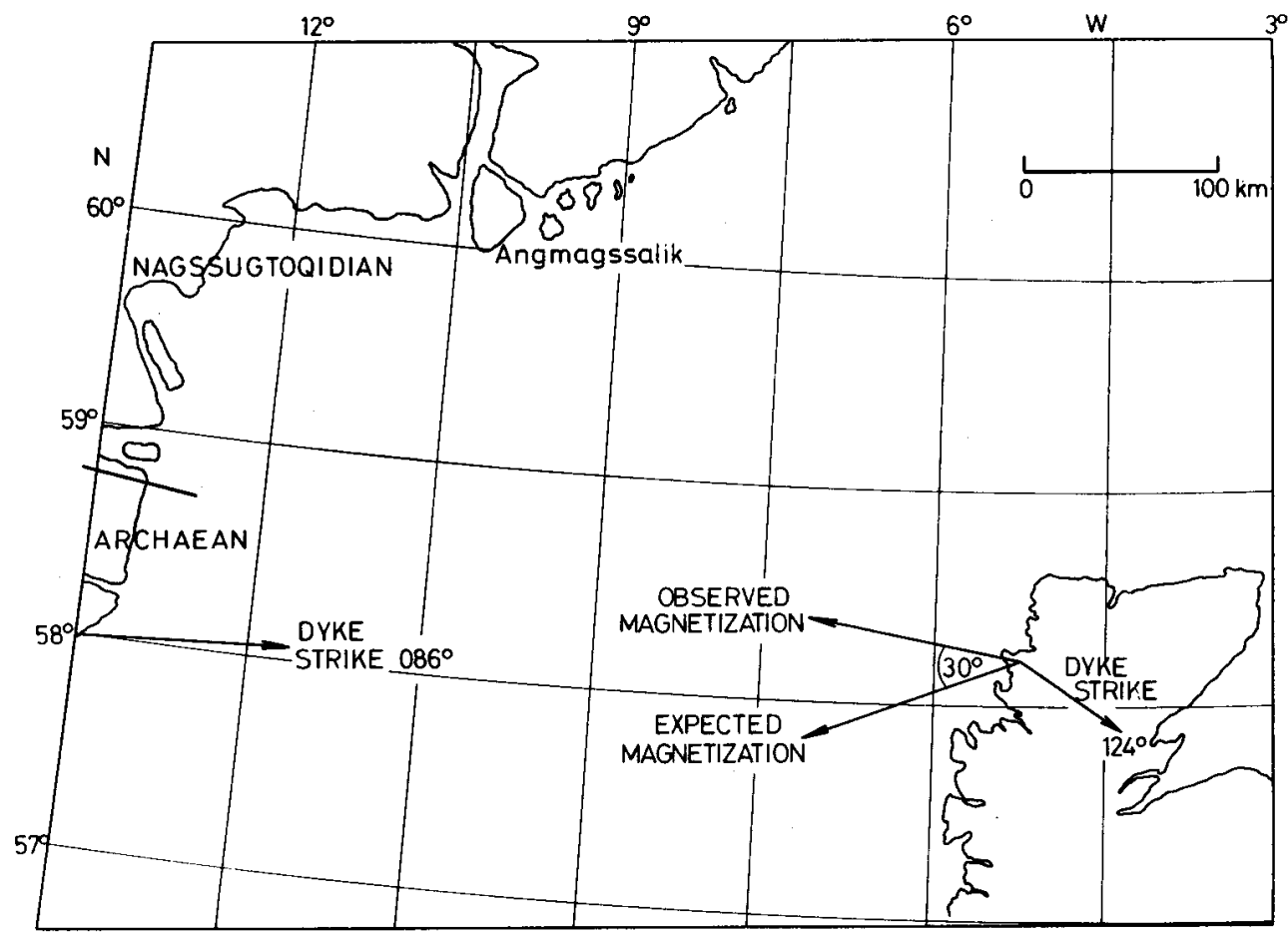

Fig. 1. A pre-drift reconstruction of the portion of the coast of East Greenland (after Bullard et al., 1965) which was adjacent to North Scotland, with Scotland in its present position.

dyke strike there would become $86( \pm 11)^{\circ}$. The great circle along the strike of these dykes would then intersect the Lewisian with a strike $90( \pm 11)^{\circ}$. The final difference in strike between the two swarms is thus $34( \pm 22)^{\circ}$, implying that the Lewisian has rotated clockwise by this angle; Escher et al. (1976) have attributed this rotation to Mesozoic plate movements.

A rotation in the same sense and approximately the same angle is apparent from comparison of late Archaean and early Proterozoic straight belts in Canada, Greenland and Scotland (Watson, 1973, fig. 2).

Palaeomagnetic evidence from Palaeozoic rocks also indicates clockwise rotation of North Scotland after magnetization; this comes from comparison of palaeomagnetic poles from Old Red Sandstones in North Scotland and Norway, although only $15^{\circ}$ rotation was apparent in this case (Storetvedt, 1974).

\section{Discussion}

In Table 1 the aforementioned palaeomagnetic poles from Greenland are set out. A striking feature of the first seven results is the similarity of the poles, in spite of the great area encompassed. These results suggest similar times of final uplift at about $1750 \mathrm{Ma}$ for these 
regions to which the Lewisian may be added. These poles are close to those of a number of rock suites of similar age in the Canadian Shield (Irving \& McGlynn, 1976); magnetization upon cooling due to uplift was also invoked for these rocks.

Another striking feature lies in the polarity of their magnetization, which has positive inclination. Of more than 2000 orientated cores from West Greenland and North-West Scotland, including the Outer Hebrides (author's data in Institute of Geological Sciences, 1977 , p. 104), all those from West Greenland have this polarity and almost all from Scotland. These observations suggest the existence of a substantial phase of constant polarity of the Earth's field. It seems likely that this is a 'Magnetic Interval' (McElhinny, 1973) like the interval of constant polarity in Permo-Carboniferous times from c. 313 to $227 \mathrm{Ma}$ (Irving \& Parry, 1963; Irving \& Pullaiah, 1976).

A long period of constant polarity of the Earth's field can be explained by relatively disturbed conditions in the core (Nagata, 1969); these will be associated with changes in the core-mantle boundary which in turn may be linked with large scale tectonic processes at the surface (Cox, 1973). The link is probably provided by through-mantle convection (Irving \& Pullaiah, 1976).

Gastil (1960) was the first to notice a strong peak in the number of radiometric age determinations at $1800 \mathrm{Ma}$; Runcorn (1962) interpreted this as a global episode of uplift and cooling due to a change in the number of convection cells in the mantle. Moorbath (1976) considers that this and other peaks mark 'accretion superevents' whose duration was probably not more than 50-150 Ma.

Similarly, directions of magnetization were also locked into the crust as it rose through particular isotherms. These directions manifest themselves by grouping of palaeomagnetic poles. The grouping of poles from the Canadian Shield in the area of the present Caribbean has been described as the "palaeomagnetic signature of the Hudsonian orogeny" (Irving \& McGlynn, 1976). Similarly the poles in the same area from Greenland and N W Scotland (after reconstruction) may be described as the palaeomagnetic signatures of the Nagssugtoqidian and Laxfordian orogenies respectively, because the three orogenies are equivalent (Kalsbeek et al., 1978). It follows that crustal levels throughout extensive tracts of West Greenland and in the Lewisian and Canada may have been similar upon cooling after these metamorphisms. It seems likely that the Magnetic Intervals recognised in West Greenland and in $\mathrm{N} \mathrm{W}$ Scotland are identical.

It is interesting to note that rates of polar wander, based on global evidence, are considered low in the time range 1850-1650 Ma (Burke et al., 1976). Another way of interpreting the evidence would be to see it as the clustering of both palaeomagnetic poles and $\mathrm{K}$-Ar ages due to uplift within this time range.

\section{References}

Badham, J. P. N. 1976: in discussion of Piper, J.D.A.: Palaeomagnetic evidence for a Proterozoic supercontinent. Phil. Trans. R. Soc. Lond. A, 280, 469-490.

Bak, J., Sørensen, K., Grocott, J., Korstgård, J. A., Nash, D. \& Watterson, J. 1975: Tectonic implications of Precambrian shear belts in Western Greenland. Nature, Lond. 254, 566-569.

Beckmann, G. E. J. 1976: A palaeomagnetic study of part of the Lewisian Complex, North-West Scotland. J. Geol. Soc. Lond. 132, 45-59. 
Beckmann, G. E. J. 1977: Palaeomagnetic investigations in South-East Greenland. Rapp. Grønland geol. Unders. 85, 84-85.

Beckmann, G. E. J. \& Mitchell, J. G. 1976: Palaeomagnetic and geochronological work in central West Greenland. Earth Planet. Sci. Lett. 30, 269-280.

Beckmann, G. E. J., Olesen, N. Ø. \& Sørensen, K. 1977: A palaeomagnetic experiment on crustal uplift in West Greenland. Earth Planet. Sci. Lett. 36, 269-279.

Bingham, D. K. \& Evans, M. E. 1976: Palaeomagnetism of the Great Slave Supergroup, Northwest Territories, Canada: the Stark Formation. Can. J. Earth Sci. 13, 563-578.

Bridgwater, D., Escher, A., Nash, D. F. \& Watterson, J. 1973: Investigations on the Nagssugtoqidian boundary between Holsteinsborg and Kangâmiut, central West Greenland. Rapp. Grønlands geol. Unders. 55, 22-25.

Bridgwater, D., Davies, F. B., Gill, R. C. O., Gorman, B. E., Henriksen, N. \& Watterson, J. 1977: Field mapping in the Nagssugtoqidian of South-East Greenland. Rapp. Grønlands geol. Unders. 85, 74-83.

Bullard, E. C., Everett, J. E. \& Smith, A. G. 1965: The fit of the continents round the Atlantic. Phil. Trans. R. Soc. Lond. A, 258, 41-51.

Burke, K., Dewey, J. F. \& Kidd, W. S. F. 1976: Precambrian palaeomagnetic results compatible with contemporary operation of the Wilson Cycle. Tectonophysics 33, 287-299.

Cox, A. 1973: Plate tectonics and geomagnetic reversals. San Francisco: Freeman. 702 pp.

Dalrymple, G. B. \& Lanphere, M. A. 1969: Potassium-argon dating. San Francisco: Freeman. 258 pp.

Escher, A., Jack, S. \& Watterson, J. 1976: Tectonics of the North Atlantic Proterozoic dyke swarm. Phil. Trans. R. Soc. Lond. A, 280, 529-539.

Fahrig, W. F. \& Bridgwater, D. 1976: Late Archaean - Early Proterozoic palaeomagnetic pole positions from West Greenland. In Windley, B. F. (edit.) The early history of the Earth, 427-439. London: John Wiley \& Sons.

Gastil, G. 1960: The distribution of mineral dates in time and space. Amer. J. Sci. 258, 1-35.

Institute of Geological Sciences. 1977: Annual Report for 1976. (London: Institute of Geological Sciences.) 202 pp.

Irving, E. 1979: Palaeopoles and palaeolatitudes of North America and speculations about displaced terrains. Can. J. Earth Sci. 16, 669-694.

Irving, E., Emslie, R. F. \& Ueno, H. 1974: Upper Proterozoic palaeomagnetic poles from Laurentia and the history of the Grenville structural province. J. geophys. Res. 79, 5491-5502.

Irving, E. \& McGlynn, J. C. 1976: Proterozoic magnetostratigraphy and the tectonic evolution of Laurentia. Phil. Trans. R. Soc. Lond. A, 280, 433-468.

Irving, E. \& Parry, L. G. 1963: The magnetism of some Permian rocks from New South Wales. Geophys. J. R. astr. Soc. 7, 395-411.

Irving, E. \& Pullaiah, G. 1976: Reversals of the geomagnetic field, magnetostratigraphy and relative magnitude of palaeosecular variation in the Phanerozoic. Earth Sci. Rev. 12, 35-64.

Kalsbeek, F., Bridgwater, D. \& Zeck, H. P. 1978: A 1950 ( \pm 60) Ma Rb-Sr whole-rock isochron age from two Kangâmiut dykes and the timing of the Nagssugtoqidian (Hudsonian) orogeny in West Greenland. Can. J. Earth Sci. 15, 1122-1128.

Larsen, O. \& Møller, J. 1968: K/Ar age determinations from Western Greenland, I. Reconnaissance programme. Rapp. Gronlands geol. Unders. 15, 82-86.

McElhinny, M. W. 1973: Palaeomagnetism and plate tectonics. Cambridge University Press, 358 pp.

Moorbath, S. 1976: Age and isotope constraints for the evolution of Archaean crust. In Windley, B. F. (edit.) The early history of the Earth, 351-360. London: John Wiley \& Sons.

Morgan, G. E. 1976a: Palaeomagnetism of a slowly cooled plutonic terrain in Western Greenland. Nature, Lond. 259, 382-385.

Morgan, G. E. 1976b: The palaeomagnetism of some Precambrian rocks from the Itivdleq region of West Greenland. Ph.D. thesis, University of London.

Nagata, T. 1969: Length of geomagnetic polarity intervals. J. Geomag. Geoelect. 21, 701-704. 
Pankhurst, R. J., Moorbath, S., Rex, D. C. \& Turner, G. 1973: Mineral age patterns in ca. 3700 m.y. old rocks from West Greenland. Earth Planet Sci. Lett. 20, 157-170.

Piper, J. D. A. \& Stearn, J. E. F. 1976: Palaeomagnetism of Ketilidian metamorphic rocks of SW Greenland, and 1850-1600 m.y. apparent polar movements. Phys. Earth Planet. Int. 13, 143-156.

Runcorn, S. K. 1962: Continental drift. Academic Press, 338 pp.

Storetvedt, K. M. 1974: A possible large-scale sinistral displacement along the Great Glen fault in Scotland. Geol. Mag. 111, 23-30.

Ueno, H., Irving, E. \& McNutt, R. H. 1975: Palaeomagnetism of the Whitestone anorthosite and diorite, the Grenville polar track and relative motions of the Laurentian and Baltic Shields. Can. $J$. Earth Sci. 12, 209-226.

Watson, J. 1973: Effects of reworking on high-grade gneiss complexes. Phil. Trans. R. Soc. Lond. A, 273, 443-455.

Watterson, J. 1974: Investigations on the Nagssugtoqidian boundary in the Holsteinsborg district, central West Greenland. Rapp. Grønlands geol. Unders. 65, 33-37.

Williams, I. S. 1975: The palaeomagnetism of north-west Scotland. M.Sc. thesis, University of Newcastle-upon-Tyne.

School of Physics,

The University,

Newcastle-upon-Tyne NE1 7RU,

U.K.
Present address: Faculty of Earth Sciences, King Abdulaziz University,

P.O. Box 1744, Jeddah, Saudi Arabia. 